\title{
POU Domain Class 2-Associating Factor 1
}

National Cancer Institute

\section{Source}

National Cancer Institute. POU Domain Class 2-Associating Factor 1. NCI Thesaurus. Code $C 97732$.

POU domain class 2-associating factor 1 (256 aa, $27 \mathrm{kDa}$ ) is encoded by the human POU2AF1 gene. This protein is involved in both the modulation of transcription and humoral immunity. 